\title{
ENTRE DOM QUIXOTE E SANCHO PANÇA: "ESPELHO DOS PRÍNCIPES” (OU SPECULUM PRINCIPIS) CERVANTINO, UMA INTERPRETAÇÃO POSSÍVEL
}

\author{
LIGIA MARIA BREMER ${ }^{1}$
}

\begin{abstract}
Resumo: A obra de Miguel de Cervantes, Dom Quixote de La Mancha, apresenta inúmeras possibilidades de interpretações, em especial entre o direito e a literatura, pois a temática do direito e da justiça é exposta de forma crítica por meio de seus episódios. Durante a Idade Média a pessoa do rei era quem guardava a ordem jurídica. Foi nesse período, a partir do século XII, que se fundamentou o princípio de ratio status que procedeu na submissão do poder à ordem éticoreligiosa, pressupondo o respeito à lei, observando a ordem justa. $\mathrm{O}$ objetivo do trabalho é analisar os conselhos dados por Dom Quixote a Sancho Pança antes de ele ir governar a Ilha de Barataria. Para tanto, se fez um levantamento bibliográfico destacando algumas obras contemporâneas ao texto cervantino. Buscou-se, além da temática "espelhos dos príncipes," a intertextualidade que possa haver com a novela cavalheiresca traçando um paralelo entre elas. Ao realizar o estudo constatou-se o quanto o direito está presente na obra de Cervantes. Os personagens Dom Quixote e Sancho Pança são representações de sujeitos de direito assemelhando-se ao instrutor e ao juiz daquele período.
\end{abstract}

PalaVras-ChaVe: Dom Quixote; Sancho Pança; intertextualidade; príncipe; espelhos

1 Mestre em Literatura pela Universidade Federal de Santa Catarina (UFSC). Bacharel em Direito pela Universidade Estadual do Oeste do Paraná (UNIOESTE). Bacharel em Letras - Língua Portuguesa e Literaturas pela Universidade Federal de Santa Catarina (UFSC). Advogada. Cascavel (PR), Brasil. ORCID: https://orcid.org/o000-0002-3908-3910.CV Lattes: http://lattes.cnpq.br/6317100564936933. E-mail: ligiabremer@gmail.com. 
A vuestra espada no igualó la mía, Febo español, curioso cortesano.

(Cervantes, 1978, p. 25)

\section{INTRODUÇÃO}

Este trabalho logo em seu título apresenta uma indagação: será Sancho Pança o "príncipe" de Miguel de Cervantes? Responder categoricamente essa questão não é o que se pretende, mas sim criar possibilidades interpretativas para um dos inúmeros caminhos possíveis a seguir com a pesquisa de Direito e Literatura em Dom Quixote, de Cervantes. Primeiramente é necessário compreender o campo interdisciplinar entre o Direito e a Literatura para contextualizar o estudo proposto. Ambas as áreas estão em constante aproximação e diálogo, dividindo o interesse por objetos que são comuns tanto aos profissionais e estudiosos do Direito quanto das letras.

O presente estudo buscará, por meio das alegorias e da ficção apresentadas em Dom Quixote de La Mancha, publicada pela primeira vez na cidade de Madri em 1605, apreender os aspectos do Direito relevantes para a reflexão sobre a formação de um governante para vir a ter a aptidão para fazer justiça.

Segundo Cintrón (2010), Cervantes faz com que o mundo do direito seja parodiado em seu texto, ou seja, em Dom Quixote existe a ocorrência de temas e situações que demonstram como a juridicidade, a legislação, as instituições podem interromper o jogo social e alcançar a plenitude do ser humano. Em Dom Quixote se vai do humano ao jurídico e do Direito ao social$^{2}$. Após a exposição de forma muito sintética das principais linhas do romance, o objetivo é analisar os conselhos dados por Dom Quixote a Sancho Pança antes de ele ir governar a Ilha de Barataria. Buscar-se-á em outras obras as possíveis intertextualidades com a novela de Cervantes, destacando e discutindo o Direito presente nessa passagem da obra e como ela pode vir a contribuir para essa área de conhecimento humano e político.

2 Discussões nesse sentido têm-se nos trabalhos de Olivo e Lehmann (2015) e Fachin (2017). O primeiro trata das questões de dimensão jurídica da loucura propondo um paralelo entre realidade brasileira e a quixotesca. Já a segundo busca (re)contar o discurso jurídico dos direitos humanos tendo por referência a obra de Cervantes. 
As trocas interdisciplinares entre o direito e a literatura começaram a ser matéria de estudo a partir da segunda metade do século XX, notadamente nos Estados Unidos, na contramão da perspectiva positivista, atuando na formação do profissional do direito e visando alinhavar alguns aspectos humanísticos, que as carreiras jurídicas acabaram por se afastar. A centralização do direito no positivismo kelseniano levou à redução gramatical de seus enunciados e à análise estritamente sintática e semântica de suas normas, tornando-o incapaz de atender às demandas sociais postas ao direito. Como resposta a essa insuficiência do reducionismo positivista, o movimento Direito e Literatura proporcionou uma miragem crítica e inovadora capaz de construir alternativas teóricas para o direito, acusando seus limites, incompletudes e contradições.

A interseção entre o Direito e Literatura é objeto de estudo de José Calvo González, que, assim como François Ost, difere o encontro entre o Direito e a Literatura em três modalidades: a primeira é o Direito na Literatura, que representa o cruzamento entre as disciplinas de uma forma mais instrumental; outra é o Direito como Literatura, que envolve uma interseção estrutural; e por fim, o Direito com Literatura, que indica uma interseção mais institucional.

Calvo González assinala:

El Derecho y la Literatura comparten una misma práctica poética. Ella no es otra que la efectiva capacidad de instituir lo social, de hacer pasar de la naturaleza a la cultura, de tipificar actos y procesos de sentido compartido, esto es, institucionalizar imaginarios sociales. Desde esa óptica la intersección Derecho $y$ Literatura que en el Derecho con la Literatura llamo por ese motivo institucional aconseja, si no reclama, al menos tres puntualizaciones a fin de constatar:

i) Que en lo jurídico y lo literario se alojan prácticas sociales instituyentes

ii) Que esa dualidad instituyente puede aprovechar del préstamo de ciertas formas literarias por los cánones de poética jurídica

iii)Que, por lo que aquí particularmente nos ocupa en interés a una Teoría literaria del Derecho, el propósito es conocer la apropiación por la práctica jurídica institucional de formas arquetípicas de la poética literaria [...] la intersección Derecho $y$ Literatura en el Derecho con la Literatura introduce una variante nueva, consistente en la apropiación por lo jurídico de la práctica literaria institucional, así pudiendo distinguirse dos modalidades, de acuerdo a la específica circunstancia con que aquélla se ejecute o suceda: con traslación 
(transporte), o con trascripción (reproducción). (Calvo González, 2008, p. 20)

Por outro lado, Junqueira, em Literatura e direito: uma outra leitura do mundo das leis (1998), considera que três são os caminhos tomados pelo movimento. O primeiro é o Direito como Literatura, em que os textos jurídicos são lidos e interpretados como textos literários. Essa corrente, ligada à dimensão hermenêutica, à retórica e à forma narrativa do texto jurídico, utiliza métodos de análise e interpretação advindos da teoria literária e elaborados para examinar a racionalidade das construções realizadas no âmbito das decisões judiciais. O segundo é o Direito na Literatura, em que a análise recai sobre obras literárias que abordam questões jurídicas, tais como julgamentos, exercício profissional ou métodos legais de punição. Nessa corrente o conhecimento auxiliaria o profissional do direito a entrar em contato com determinadas experiências legais. E finalmente, tem-se o Direito da Literatura que referencia questões legais do direito autoral, sendo discutida por outra vertente do Direito.

O Direito e Literatura, segundo Godoy (2002), tem relevância, uma vez que a literatura pode fornecer tanto informações quanto subsídios para que o meio social em que o direito se desenvolve seja compreendido. $\mathrm{O}$ autor acredita ser possível conhecer o direito por meio da Arte, evidenciando que ele não se dá sob o âmbito normativo e, nesse sentido, a literatura possibilita a apreensão do jurídico como um produto cultural, enfocando a época e suas instituições.

É necessário atentar, também, para a opinião de Ronald Dworkin, sobre as relações entre Direito e Literatura. A proposta apontada por ele é "que podemos melhorar nossa compreensão do direito comparando a interpretação jurídica com a interpretação em outros campos do conhecimento, especialmente a literatura" (Dworkin, 2000, p. 217). É na literatura que mais largamente se usa o espaço da interpretação, sendo o próprio discurso literário uma tentativa de interpretar a realidade. Devido a esse fato, Dworkin sugere que é possível estudar a interpretação como uma atividade geral, como um modo de conhecimento, atentando para outros contextos dessa atividade. Para o autor, as leituras possibilitam procedimentos hermenêuticos que revelam reservas de sentido, 
descortinando a vida real de enredos e tramas. A interpretação cria o texto, do mesmo modo em que dá origem e vida ao Direito.

Na mesma posição de Dworkin, François Ost, em Contar a lei (2005), também defende a literatura como libertadora dos caminhos disponíveis ao homem frente à realidade codificada no direito. Para Ost, no entanto, a vantagem desse estudo encontra-se no fato de que, embora ambos os campos de conhecimento descrevam as relações humanas, a literatura liberta das amarras formais e práticas do direito. A renovação do direito dáse pelo choque com as proposições artísticas da literatura e gera uma rediscussão de questões fundamentais ao direito, tais como-a ordem social, as leis e o poder.

O Direito surge na obra de Arte por vezes não direta e literalmente. Ele se explícita ou se implícita em certa relação estética e temática com a ciência jurídica juntamente com suas diversas representações, utilizando de alegorias, fábulas, paródias, poesia e ficção, como sustenta Carmelo Delgado Cintrón (2010). O jurista acrescenta ainda que - quando a literatura apresenta relações sociais - o Direito, a legislação, o jurídico e as instituições, assim como a história e as tradições, possuem tanta significação para a vida social que ignorá-los implicaria descartar parte da sociedade e da sua realidade.

\section{ASPECTOS DE DOM QUIXOTE DE LA MANCHA: A DUALIDADE DE DOM QUIXOTE E SANCHO PANÇA}

Como já apontado, Dom Quixote de La Mancha é uma obra escrita no início do século XVII, sendo composta de 126 capítulos, divididos em duas partes, em duas publicações com espaço de dez anos, sendo o primeiro publicado em 1605 e o segundo em 1615. O romance, considerado um dos melhores livros de ficção de todos os tempos 3 , narra as aventuras de um fidalgo castelhano que, após ler inúmeros livros de cavalaria, decide viver suas próprias aventuras como cavaleiro andante. Quem o acompanha é Sancho Pança, seu fiel amigo, o qual diversamente do companheiro possui

3 Em 2002, foi realizada uma votação organizada pelos Clubes do Livro Noruegueses que contou com a participação de escritores de reconhecimento internacional como: Salman Rushdie, Milan Kundera, John Le Carre, John Irving, Nadine Gordimer, Carlos Fuentes e Norman Mailer. A eleição fez parte da campanha para promover a leitura de clássicos contra os desafios da televisão, vídeo e jogos de computador. 
uma visão mais realista dos fatos. A ação do romance gira em torno de expedições, e são nessas incursões que a dupla vivência suas aventuras, por vezes fantasiosas, porém desmedidas pela dura realidade.

Dom Quixote e Sancho Pança representam valores distintos. O primeiro é descrito por Cervantes de uma forma antagônica, ou seja, ora apresenta-se lúcido e ora sem juízo. Isso acontece porque o fidalgo buscava seguir todos os passos apresentados por seus livros de aventuras de cavalaria, levando-o a loucura. No entanto, conselhos e conclusões feitas por ele em alguns episódios não apresentam essa falta de discernimento, como no caso exposto, a seguir, dos conselhos dados a seu escudeiro quando foi governar a ilha de Barataria. O segundo, Sancho Pança, é apresentado pelo autor no sétimo capítulo - "Da segunda saída do nosso bom cavaleiro Dom Quixote de La Mancha" - sendo designado como um "homem de bem [...] e de pouco sal na moleira" (Cervantes, 1978, p. 53). Porém, apesar dessa descrição, o antigo lavrador é o representante do bom senso para o mundo real, diferindo de Dom Quixote que representa o "bom", mas para o mundo ideal. Nesse sentido, Ian Watt (1997) aponta Dom Quixote como sendo um dos mitos do individualismo moderno e afirma: “[...] a sabedoria da loucura de Sancho é o perfeito complemento da loucura de Quixote” (Watt, 1997, p. 88). Acrescenta ainda que Cervantes, ao apresentar seus principais personagens com um senso de humor e uma concretude indestrutível, faz com que eles não possam ser confinados nos limites de nenhuma padronizada tendência de oposição social, moral ou psíquica. Dom Quixote e Sancho Pança não são opostos, cada um deles adquire traços do outro no decorrer de sua convivência. Watt salienta também que "Cervantes exagerando as grandes diferenças entre os dois no plano moral e intelectual, tenha reforçado suas afinidades nos planos emocional e humano" (Watt, 1997, p. 89).

Resumir essa obra de Cervantes é algo difícil em face das inúmeras aventuras vivenciadas pelos dois personagens principais. Vladmir Nabokov elaborou uma relação com as vitórias e derrotas do herói de La Mancha e mostra que “[...] em seus recontros Quixote obtém vinte vitórias, perfeitamente compensadas por vinte derrotas" (Nabokov apud Watt, 1997, p. 64). Dom Quixote, antes de se aventurar pelo mundo em sua vida de cavaleiro andante, era um fidalgo pobre, integrante do mais baixo escalão 
da nobreza espanhola, de sobrenome Quijada ou Quesada - essa não exatidão "pouco faz para a nossa história" (Cervantes, 1978, p. 29), afirma o narrador -, com aproximadamente cinquenta anos e vivia em uma aldeia em La Mancha. Em seu tempo livre, "que eram os mais do ano" (Cervantes, 1978, p.29) se ocupava em ler livros de cavalaria. A leitura passou a ser uma obsessão, tanto que chegou a vender boa parte de suas terras para adquirir novos livros de cavalaria. Ao seu ver "não havia história mais certa no mundo" (Cervantes, 1978, p. 30) do que as invenções e fantasias contidas nesse mundo. Decidiu, então, tornar-se um cavaleiro andante, deixando sua identidade para sair pelo mundo, levando a justiça e a ajuda para a república dos desvalidos. Para iniciar sua jornada limpa algumas armas herdadas de seus bisavôs que se encontravam guardadas. Em seguida, passa dias para escolher o nome de seu cavalo e o seu próprio nome, Rocinante e Dom Quixote, respectivamente. Sancho Pança, como dito anteriormente somente aparece no capítulo sétimo, após o retorno de Quixote de suas primeiras andanças. Tido como louco pelos seus próximos (a sobrinha, a ama, o barbeiro e o cura), após uma estadia de aproximadamente quinze dias, decide retomar sua jornada, contudo convida um lavrador, seu vizinho, para acompanhá-lo como escudeiro e em troca promete uma das ilhas das terras que iria conquistar. Assim, os caminhos de Dom Quixote e Sancho Pança se cruzam, e as aventuras com os dois se iniciam.

As polaridades desses personagens se apresentam de maneira fundamental para entender o episódio a ser discutido em seguida, os conselhos e a forma de governar apresentada na segunda parte do romance. A maneira como os personagens são representados fisicamente, sendo um alto e magro e outro baixo e gordo, são característica que muito bem podem esboçar inicialmente as dualidades de ordem geral e simbólica que os personagem possuem. Watt salienta:

No plano psicológico Quixote e Sancho representam as polaridades do espírito e da carne, cérebro e estômago, céu e terra, sonho e realidade, passado e presente, literatura e vida; na esfera social, evidencia-se a dicotomia de cavaleiro e camponês, do herói autoproclamado em face do covarde confesso, de introvertido e extrovertido, de solitário e de gregário, de solteirão e homem casado (1997, p. 85). 
George Orwell, em “The Art of Donald McGill” (1941), trata da vinculação extrema existente entre os principais personagens de Dom Quixote e observa que as mesmas composições estão presentes nos seres humanos em geral, não sendo, portanto, uma particularidade do cavaleiro e seu escudeiro:

Dois princípios, loucura fidalga e sabedoria plebéia, existem lado a lado em quase todos os seres humanos. Se examinarmos a nossa própria mente, a que conclusão chegaremos sobre nós? somos (sic) Dom Quixote ou Sancho Pança? É quase certo que acabaremos por descobrir que somos os dois. Uma parte de nós gostaria que fôssemos um herói ou um santo, enquanto a outra é um homenzinho gordo que só enxerga as vantagens de nos mantermos vivos e com todos os ossos nos respectivos lugares. Ele é o nosso eu não oficial, a voz da barriga protestando contra a alma...é pura mentira dizer que ele não mora no nosso lá dentro, do mesmo modo que mentimos ao dizer que Dom Quixote não é parte de nós (Orwell apud Watt, 1997, p. 85).

Dom Quixote é um romance atrativo por possibilitar ir além do mito.

Ele contém uma profunda sabedoria em suas linhas que permite fazer uma relação próxima com o ser humano. Apesar de ser um romance datado do século XVII muito se consegue correlacionar com o homem dos dias atuais como nos explicou Orwell.

As diferentes características de Dom Quixote e Sancho fazem com que percebamos o quanto eles se completam, e essa pequena análise feita até o momento será necessária para entendermos o desenrolar das ações e reações que ocorrerão nos episódios em que Dom Quixote aconselhará seu escudeiro e como este deverá se portar ao governar sua ilha.

\section{SÍNTESE DOS FATOS: O ENCONTRO COM O CASAL DE DUQUES QUE ANTECEDE O ACONSELHAMENTO}

O episódio selecionado para ser estudado neste trabalho se encontra na segunda parte da obra, sendo a parte central da terceira expedição de Dom Quixote e Sancho Pança. Nesse momento da história aparecem dois novos personagens, os quais são de elevada importância: o duque e a duquesa, que já haviam lido a primeira parte das aventuras do cavaleiro Dom Quixote e ao encontrá-los passaram a se divertir as suas custas. A principal brincadeira desencadeada por eles é o arranjo para Sancho tornar- 
se governador interino de uma ilha, porém não de uma ilha conquistada por Quixote, mas de uma cidade pertencente ao ducado.

O encontro com os Duques ocorre em um bosque e é antecedido pelos planos desanimadores de Sancho de um dia ir embora e deixar a vida de escudeiro, que para ele não traz nenhuma vantagem. Dom Quixote e Sancho observam à distância os nobres senhores impressionados pela riqueza. Dom Quixote pede a Sancho que se dirija até a duquesa e "dize àquela senhora do palafrém e do garifalte, que eu, o Cavaleiro dos Leões, beijo as mãos à sua grande formosura" (Cervantes, 1978, p. 432). Nesse pedido recomenda a Sancho o cuidado com a maneira de falar. A solicitação foi cumprida na íntegra pelo escudeiro, no entanto o próprio Dom Quixote demonstra a sua fragilidade caindo do seu cavalo Rocinante quando vai apeá-lo.

O Duque e a Duquesa - por já conhecerem previamente a história do cavaleiro e seu escudeiro - convidam Dom Quixote e Sancho para passar alguns dias em seu palácio, e eles vão, esperando gozar de uma autêntica estada cavalheiresca. Nesse episódio é possível perceber como Quixote deseja que Sancho fale o menos possível, principalmente para cuidar da sua imagem. No entanto, os Duques os estimulam a falar bastante. Nesse momento, a "luta de Dom Quixote para ser aquilo que gostaria de ser é substituída por um desejo persuasivo de parecer aquilo que não é” (Vieira, 1998, p. 103).

$\mathrm{Na}$ chegada ao palácio, Sancho demonstra excessivos cuidados com seu jumento, do que decorre uma discussão com Dona Rodriguez - uma dama da Duquesa um pouco mais idosa. Em seguida há o almoço com a presença de um religioso contrário às novelas de cavalarias, que proporciona um debate entre Dom Quixote e o Eclesiástico sobre a cavalaria andante. O oferecimento da Ilha de Barataria a Sancho também ocorre neste trecho.

Para Maria Augusta da Costa Vieira (1998), é a partir desse momento, do encontro com os Duques e a estadia em sua casa, que as ações passam a ser friamente calculadas e idealizadas pelos Duques com o auxilio de sua criadagem. A primeira delas é a caça ao javali, a qual remete aos mitos da novela de cavalaria. Em seguida, tem-se a aventura preparada para separar Dom Quixote e Sancho: o primeiro permanece no palácio, e o segundo vai 
ocupar o cargo de governador em Barataria. A partir daí segue uma sequência narrativa intercalada de capítulos que se concentram ora em Quixote, ora em Sancho.

Antes da ida de Sancho para a Ilha de Barataria, nos capítulos XLII e XLIII, Dom Quixote faz algumas recomendações a seu fiel escudeiro para o novo desafio ao qual irá se lançar: o de governador. São esses conselhos que serão abordados, buscando juntamente apresentá-los e discuti-los.

\section{“ESPELHO DOS PRÍNCIPES" NA LITERATURA MEDIEVAL E A INTERTEXTUALIDADE COM DOM QUIXOTE}

A obra Dom Quixote, é conhecida como um romance que parodia as novelas de cavalaria. Dessa forma, ao analisá-la podemos perceber as diversas possibilidades de interpretações intertextuais a serem feitas. Julia Kristeva em Introdução à semanálise (1974) pontua:

[...] a palavra literária não é um ponto (um sentido fixo), mas um cruzamento de superfícies textuais, um diálogo de diversas escrituras: do escritor, do destinatário (ou da personagem), do contexto cultural atual ou anterior. [...] todo texto se constrói como mosaico de citações, todo texto é absorção e transformação de um outro texto. Em lugar da noção de subjetividade, instala-se a intertextualidade e a linguagem poética lê-se pelo menos como dupla (1974, p. $62-64)$.

A intertextualidade na obra de Cervantes com a "literatura dos Espelhos"4 pode ser notada já no início da primeira parte do romance, no soneto "O Cavaleiro do Febo a Dom Quixote de La Mancha", que na primeira estrofe apresenta os seguintes versos:
A vuestra espada no igualó la mía, Febo español, curioso cortesano, $\mathrm{Ni}$ a la alta gloria de valor mi mano, Que rayo fué do nasce y muere el día.
(Cervantes, 1978, p. 25, grifo nosso)

Nesses versos podemos constatar a intertextualidade com a obra de Diego Ortúñez de Calahorra, Espejos de príncipes y caballeros, também conhecida por El Caballero Del Febo. Como o título já indica, vincula-se aos espelhos dos príncipes medievais propondo modelos ideais de conduta cavalheiresca e cortesã, para que aqueles que vierem a ler o manual possam

4 Cita-se apenas a "literatura dos espelhos", pois em um estudo mais atento é possível verificar outras intertextualidades como o romance de cavalaria da época Madís de Gaula, de Rodrigues de Montalvo. 
refletir e aprender, principalmente os jovens nobres. Essa intertextualidade evidencia como a tradição dos "espelhos" está presente na obra de Cervantes, pois o episódio de aconselhamento de Dom Quixote a Sancho reporta-se a essa literatura de manuais na qual são oferecidas ao futuro monarca as lições necessárias para a sua formação e aprendizagem para exercer a governança. E, da mesma forma como ocorre em Dom Quixote, nas obras que tematizam o "espelho dos príncipes" são detalhadas virtudes e façanhas dos personagens.

Além da relação com a obra de Ortúñes de Calahorra, podemos fazer aproximações com outras obras da época medieval, contemporâneas ou não a Dom Quixote. David Nogales Rincón, em seu texto Los Espejos de Príncipes em Castilla (siglos XIII-XV): un modelo literario de la realeza bajo medieval, apresenta uma definição para a melhor compreensão da "literatura dos espelhos":

Los espejos o tratados de educación de príncipes son obras de carácter político-moral que recogen un conjunto de directices morales y de gobierno básicas que han de inspirar la actuación del buen soberado cristiano. Por ello, estos tratados se convertirán, en un sentido figurado, en espejos en los cuales todo príncipe cristiano debería mirarse para guiar su actuación. No obstante, éstos frecuentemente incluyen refeencias a aspectos diversos, entre los que cabría destacar el mundo de la Corte y la administación real. (Rincón, 2006, p.10)

Durante a Idade Média, a pessoa do rei era a autoridade responsável pela garantia da ordem jurídica. Assim, detinha todo o poder político e jurídico da sociedade pertencente ao seu reinado. Porém, não somente o direito comum fazia parte do arcabouço legislativo, o direito canônico também estava presente. Em meados do século XII, desenvolve-se o conceito de ratio status, que acarreta a submissão do poder à ordem éticoreligiosa, pressupondo o respeito à lei, observando a boa ordem, a ordem justa.

Estudioso em história do direito, Bercovici ensina: “A ratio status não é um princípio de exceção, mas um princípio permanente de conduta do poder político, cuja essência é agir segundo a justiça” (2008, p. 52). Dessa forma, paulatinamente, e não de forma absoluta, o rei toma para si o papel de legislador, indo além do mero cumpridor da lei para ser a autoridade que derroga o direito. O pressuposto que lhe conferia esse poder de derrogar as 
leis veio do direito comum: legem non habet, que determinava quais situações limites de necessidade pública e com justa causa o rei teria a autorização para suspender o direito e, assim, legislar da forma pela qual entendesse que traria a estabilidade para seu governo. No entanto, tal dispositivo, desde Aristóteles, estabelece uma discussão que infere no governante justo ou tirano.

A partir desses pressupostos históricos, é necessário analisar algumas obras submetidas a esse tipo de governança de razão de Estado, em que a necessidade está presente e descolada do discurso jurídico-religioso. Por conseguinte, adotam o conceito ratio status, a mesma linha à qual Dom Quixote segue ao aconselhar Sancho Pança.

A primeira obra selecionada é Da razão de Estado, do italiano Giovanni Botero, publicada em 1589, em Veneza, que traz em seu contexto a transformação das relações políticas ocorridas na passagem do mundo medieval para o moderno, destacando o poder político do governante. Bercovici (2008) assinala a proposta de Botero como sendo de uma razão de Estado cristã, que integra a necessidade ao discurso jurídico-religioso da ratio status. Essa obra merece ser destacada, pois existe uma intertextualidade com a novela cervantina, visto que, em $D a$ razão do Estado, também o autor aconselha os príncipes católicos sobre quais ações e atitudes são as melhores para manter a própria grandeza e conseguir o desenvolvimento e a manutenção do Estado, assim como o faz Quixote em relação a Sancho Pança. Tini aborda os aspetos do decoro em Dom Quixote e aponta:

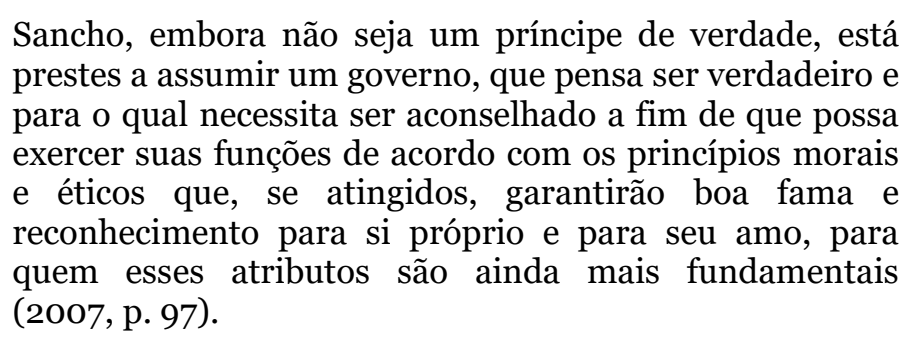

Outra obra relevante da época medieval, porém não contemporânea a Dom Quixote, mas de significativa importância, é a do inglês John of Salisbury, Policraticus, datada de 1159. Essa obra apresenta uma espécie de manual de bom comportamento, pretendendo fazer com que os príncipes governassem de acordo com o bem comum. Bercovici explica: “[...] a visão de Salisbury é organicista, entendendo a sociedade como um organismo 
natural, um corpo político, cuja cabeça é ocupada pelo príncipe, responsável não só pela proteção da fé-cristã, mas também pela conservação do organismo político" (Bercovici, 2008, p. 53). O príncipe, em Policraticus, agiria de acordo com a razão do bem do povo, de acordo com as leis de Deus e dos homens. Da mesma forma, como a obra anterior, esta apresenta as mesmas características, trata da ratio status, além de ser uma forma de aconselhamento aos príncipes para uma boa governança. Sua relevância advém do fato de existirem muitas similaridades com os conselhos dados a Sancho Pança.

O jurista Jean Bodin, em Os seis livros da Republica, também criou seu próprio príncipe, que separa o Estado da religião por meios exclusivamente jurídicos. Embora o príncipe esteja vinculado às leis divinas e naturais, sua ação para proteger o seu reino pode ser feita utilizando qualquer meio. Para Bodin, "a paz interna constitui o Estado, com a unidade religiosa sacrificada pela unidade estatal" (Bercovici, 2008, p.65). O soberano é limitado pelas leis fundamentais do Reino, pela lei divina e pela lei natural, mas não deixa de ser soberano:

\begin{abstract}
O soberano para Bodin é a origem da lei, mas ela não é mera expressão da sua vontade. Ela não pode contrariar a razão, o direito natural e o direito divino. O soberano deve obedecer à lei divina e à lei natural. Ao produzir o direito, o soberano é análogo a Deus, mas não é Deus. Não é possível, para Bodin, o conflito entre razão de Estado (expressão aliás que não utiliza) e o direito. $\mathrm{O}$ poder só é soberano se for um "correto governo" (Bercovici, 2008, p. 66-67)
\end{abstract}

A seleção do príncipe de Bodin para o estudo se faz quando observamos o quesito do respeito à lei divina. Para Bodin, o comportamento do soberano não deve contrariar a razão, o direito natural e divino, assemelhando-se a Deus. O "governo correto" é que traz a credibilidade para o príncipe. Paralelamente, no caso de Dom Quixote, é Sancho Pança que almeja governar seguindo as premissas divinas.

Necessária também é a análise de $O$ príncipe, de Nicolau Maquiavel, escrita em 1513 e publicada, postumamente, em 1532. É possível afirmar que se trata de uma obra contemporânea a Dom Quixote e igualmente as demais consiste em um tratado político importante, pois traz em seu escopo orientações para os príncipes governarem melhor seus reinados. Mas, diversamente das outras obras, esta apresenta o ratio status separado da 
necessidade. Para Maquiavel, "os fins justificam os meios”, ou seja, "A necessidade é, portanto, a regra de prudência a que o príncipe está submetido em suas ações. Ele não está subordinado a nenhuma normatividade ética, jurídica ou religiosa superior" (Bercovici, 2008, p. 62). Assim, existe uma separação nítida entre política e religião. Com $O$ príncipe, constata-se que, em meio a tantos manuais de príncipes em que o cristianismo é o principal fundamento, há um regimento de príncipes que visa a sobrepor a "engenharia política" à prudência, como acontece em Maquiavel e não é o pretendido por Cervantes em Dom Quixote.

Outras obras ainda são tidas como manuais de príncipes e possivelmente podem ter sido intertextualizadas na novela de Cervantes, como a Educación del Príncipe, de Erasmo de Rotterdam (1469-1536), que apresenta a idéia de bem comum em oposição ao bem particular e de que o príncipe obtém o êxito por meio do exercício da virtude concretizada na sabedoria, na justiça, no equilíbrio e na previsão. Essa obra surge em reação ao Príncipe de Maquiavel: "Lo que podríamos denominar 'repulsa a $E l$ Príncipe de Maquiavelo y sus tesis', es total y palmaria, y ante ello propone Erasmo un acendrado pacifismo y, al tiempo, un auténtico espejo de calidades y cualidades éticas y cívicas al futuro príncipe" (Suárez Quevedo, 2009, p. 126).

Têm-se também as obras de J. L. Viveres, com Diálogos sobre la educación, datada de 1539, do Frade Antonio de Guevara, com Libro áureo de Marco Aurelio emperador, e ainda de Furió Ceriol, a qual ensinava que seu príncipe "debe aprender su cualificadísimo oficio, primordial para el reino y, como entonces era entendido, pleno de dignidad y majestad, sobre lo cual deben incidir, ante todo, los consejeros, insistiendo en lo qué debe hacer más que en lo qué puede hacer dicho príncipe (Suávez Quevedo, 2009, p. 133).

Cita-se ainda Bartolomeo Platina com De vero príncipe, 1470; Diomede Carrafa, com De regís et boni principis officio, c1481; Francesco Patrizi de Siena, com De regno et regis institutione, 1484; e Ioannis Ioviani Pontano, De principe líber, c1503. Esses são alguns dos regimentos para príncipes pertencentes à tradição gótica literária das quais destacamos, em maior número, o "espelho dos príncipes", ao qual acreditamos que Cervantes se assemelha. 
Diante disso, observam-se os diversos "príncipes" presentes na literatura e quais os papéis desempenhados para serem modelos ideais de governabilidade. A partir desses exemplos, trata-se de verificar se Sancho Pança também pode ser interpretado como um "príncipe", ou seja, o modelo que Cervantes utilizou para apresentar suas intenções de como um soberano deveria governar, e quais as interferências dessas obras no texto de Cervantes.

\title{
ARGUMENTAÇÃO UTILIZADA POR DOM QUIXOTE PARA ACONSELHAR SEU "PRÍNCIPE" SANCHO PANÇA
}

Os principais conselhos dados por Quixote a Sancho Pança se encontram nos capítulos XLII e XLIII - Dos conselhos que deu Dom Quixote a Sancho Pança, antes de ele ir governar a ilha, com outras coisas bem consideradas e Dos segundos conselhos que deu a Dom Quixote a Sancho Pança, respectivamente. O capítulo XLII começa com a notícia da satisfação dos Duques ao perceberem o resultado alcançado com suas “burlas”. Dando sequência a tais práticas, o Duque se aproxima de Sancho e lhe dá a notícia de que este irá finalmente governar a ilha que lhe havia sido prometida por Dom Quixote no início de suas expedições.

Sancho, apesar da notícia inesperada, demonstra estar muito à vontade diante de tal fato e revela ao Duque:

\begin{abstract}
- Desde que desci do céu, e desde que vi a terra lá dessas alturas, e me pareceu tão pequena, esfriou em parte o desejo grande que eu tinha de ser governador; porque, digam-me: que grandeza é mandar num grão de mostarda, ou que dignidade ou que império é governar em meia dúzia de homens do tamanho de avelãs, que me pareceu que em toda ela não havia mais? Se Vossa Senhoria fosse servido de me dar uma pequena parte do céu, ainda que não fosse de mais de légua, tomá-la-ia de melhor vontade que a maior ilha do mundo (Cervantes, 1978, p. 476-477).
\end{abstract}

No texto acima transcrito, Sancho revela que o seu desejo de governar uma pequena ilha havia sido abatido, pois a imensidão do céu lhe mostrou que até mesmo a maior ilha do mundo se tornou pequena. Mas, ainda assim, sente-se agraciado pela possibilidade de se tornar governador. 
Sancho continua dialogando com o Duque até o momento em que Dom Quixote se aproxima. Nessa ocasião, Dom Quixote sente-se na obrigação de falar com Sancho e aconselhá-lo a propósito dessa nova posição a qual estava prestes a assumir, sentiu que deveria orientá-lo sobre como deveria atuar em relação a seu governo, bem como acerca do seu comportamento e atitudes, pois sabia que Sancho não dominava as regras ou códigos do universo ao qual estava na iminência de integrar. Outro ponto que Dom Quixote tinha consciência era do dever de direcionar seu escudeiro no exercício do governo, pois o bom resultado requeria astúcia e perspicácia. Em meio a essas indagações e preocupações, Quixote conversa pausadamente com Sancho, colocando a ele suas ponderações.

No modo como Quixote fala com Sancho, percebe-se que a forma e o conteúdo do discurso utilizado pelo cavaleiro andante são elaborados de maneira a nos remeter às práticas retóricas. Tal relação é aceitável se a retórica é entendida como um meio de persuadir o ouvinte, pois, "a retórica e o estudo da retórica têm em vista a criação e elaboração com fins persuasivos [...] como um corpo de conhecimento organizado num sistema ou método, com o fim de atingir um determinado objectivo prático" (Mesquita, 2005, p. 23). Ferraz Jr, em a Função social da dogmática jurídica (1998), ao discutir a dogmática e a persuasão, expõe que: “o discurso dogmático não é um discurso meramente informativo, no sentido de que o emissor se limita a comunicar uma informação sem se preocupar, mas sim um discurso eminentemente persuasivo, no sentido de que o emissor pretende que sua informação seja acreditada pelo receptor" (Ferraz Jr, 1998, p. 177-178). Dessa forma, o discurso de Quixote é retórico e dogmático, pois:

[...] um discurso que intenta motivar condutas, embora não se confunda com discursos prescritivos [...]. A verdade entra no discurso persuasivo como um instrumento de motivação. [...] a Dogmática põe a verdade entre parênteses e se preocupa mais com o verossimilhante, isto é não exclui a verdade, mas ressalta como fundamental a versão da verdade (Ferraz Jr, 1998, p. 178).

Assim, Dom Quixote buscou por meio do seu discurso convencer Sancho, ou seja, persuadir-lo com seus dizeres, visando a lhe proporcionar caminhos melhores no seu novo desafio. Dom Quixote utilizou dos elementos retóricos para gerar a persuasão, para motivar e ajudar Sancho 
de forma a convencê-lo - pois, apesar de no final da conversa ter dito que poderia esquecer, solicitou que esses mesmos conselhos fossem escritos para ele os ter por perto caso a memória falhasse. Quem não acata aquilo que lhe é falado simplesmente esquece, não imaginaria tê-lo por perto para poder consultar. A intervenção feita por Quixote na situação foi fundamental, sua ação de preparar Sancho para a possibilidade de realizar a tarefa de ser um bom governador garantiria não só seus próprios méritos na condição de governante, mas exaltaria também o nome e a notoriedade de seu protetor.

Como já frisado anteriormente, a retórica não é um produto de mera idealização de princípios nascidos e convencionados para persuadir pessoas, mas sim o produto de experiências consumadas, resultante da análise da estratégia escolhida pelo orador (Aristóteles, 19--). Nesse sentido, no caso em discussão, Dom Quixote tem em seu passado a fonte da experiência e conhecimento, local que resgata os requisitos básicos para nortear a prática de ações prudentes e discretas que pretende passar para seu escudeiro (Dom Quixote antes de ser um cavaleiro era um fidalgo e sabia das relações e comportamentos para a organização de uma sociedade). Quixote possuía a autoridade para realizar esse aconselhamento, porque, além de se sentir um protetor, era superior hierarquicamente a Sancho, em diversos quesitos: era seu superior na relação de trabalho cavaleiro/escudeiro, era quem dava as ordens, também era mais letrado e supunha portar melhor entendimento sobre as regras da sociedade. Os conselhos apresentam a prudência e a discrição de um cavaleiro, sendo sempre exemplificados com uma situação concreta, para o melhor entendimento pelo receptor. Também versam sobre o agir de acordo com a moral medieval e com a natural inclinação do bem. Assim, nesse grupo de capítulos, Dom Quixote é apresentado como um indivíduo perfeito, já que demonstrou ser capaz de unir os preceitos morais aos padrões e comportamentos e práticas sociais (Tini, 2007).

Outro ponto a ser ressaltado, antes de uma análise mais detalhada sobre os conselhos, é que Dom Quixote, no momento do encontro com Sancho para fazer as suas recomendações, está no uso pleno das suas habilidades mentais, pois como informa o narrador: "[...] muitas vezes se tem observado no decurso desta grande história, só disparatava no que 
dizia respeito à cavalaria, e em tudo o mais mostrava ter claro e desenfadado entendimento [...]" (Cervantes, 1978, p. 479). Essa informação é importante para trazer a credibilidade para a ocasião, uma vez que em grande parte do enredo Quixote se apresenta em estado de loucura. Porém, nesse momento, o cavaleiro consegue avaliar e interpretar a situação que Sancho está prestes a encarar, o de governante. Dom Quixote em seu discurso diz que almeja aconselhá-lo para “[...] teres um norte e um guia que te encaminhe e te leve a salvamento neste mar proceloso em que te vais engolfar, que os ofícios e grandes cargos não são outra coisa senão um gólfão profundo de confusões." (Cervantes, 1978, 478).

Os conselhos são separados didaticamente por Dom Quixote entre àqueles para "adornar a alma" e os para "adornar o corpo", isto é, enquanto um referencia o interior do sujeito, sua subjetividade, o outro remete ao exterior, à objetividade, às ações para com os outros. Tanto os conselhos para "adornar o corpo" quanto os para "adornar a alma”, são de extrema importância para um príncipe, ambos estão presentes nos manuais de boa conduta. Interessam, neste estudo, apenas aos conselhos para "adornar a alma”, em que serão discutidas algumas particularidades de cada conselho, correlacionando com as intertextualidades possíveis das obras apresentadas anteriormente e a importância para o futuro governo de Sancho.

\section{DOS CONSELHOS PARA “ADORNAR A ALMA"}

Os conselhos designados por Dom Quixote como sendo para "adornar a alma”, se encontram no capítulo XLII da obra, são em número de quinze e abordam temas como temor a Deus, humildade, compaixão e justiça. O governo de Sancho representa uma ação política dentro da novela, destacado da narração fantasiosa e um pouco fora da realidade que toma grande parte da trama, porém nesse momento a realidade se apresenta no aconselhamento de Dom Quixote a seu escudeiro.

O primeiro conselho de Dom Quixote a Sancho Pança é: “[...] hás de temer a Deus, porque no temor de Deus está a sabedoria, e, sendo sábio em nada poderás errar" (Cervantes, 1978, p. 478). Observando o conselho de Quixote, a sabedoria vem do temor de Deus e somente o sábio não erra. Um princípio lógico é proposto por Quixote: se temer a Deus será sábio, se for sábio não errará, então se temer a Deus não errará. Com exceção d’O 
Príncipe de Maquiavel, o mesmo princípio encontra-se presente nas demais obras citadas anteriormente neste estudo. Em Botero, Da Razão de Estado, por exemplo, o temor a Deus aparece ao longo de todo o texto e trata de uma teoria em que são dados conselhos a príncipes cristãos, para os quais a moral e os princípios religiosos, assim como Deus e a Igreja, são colocados acima de tudo. O mesmo ocorre em Policraticus, de John of Salisbury, e no "príncipe" de Bodin, ou seja, os governantes devem observar as leis de Deus em suas decisões. Porém, o "príncipe" de Bodin, em caso de extrema necessidade, poderá até deixar de observar seus princípios. Acompanhando o entendimento, Maria del Carmen Rivero Iglesias, especialista em literatura espanhola do Século de Ouro, ensina que "Cervantes encara en Sancho su peculiar propuesta literaria del príncipe cristiano que toma como primer fundamento ético de su gobierno el repeto hacia Dios adscribiéndolo, así, a la corriente antimaquiavélica de la época” (Rivero Iglesias, 2009, p. 121) .

O segundo conselho refere-se ao autoconhecimento:

[...] põe os olhos em que és, procurando conhecer-te a ti mesmo, que é o conhecimento mais difícil que se pode imaginar. De conhecer-te resultará o não inchares como a rã, que se quis igualar ao boi: que se isto fizeres, virá a ser feios pés da roda da tua loucura a consideração de teres guardado porcos na tua terra (Cervantes, 1978, p. 478).

Sobre esse conselho, Tini (2007) salienta que sua posição logo entre os primeiros é proposital. Concordamos com a pesquisadora, pois após haver a proteção de Deus (e consequentemente a sabedoria) é imprescindível o conhecimento próprio. O autoconhecimento representa uma característica necessária do governante para que tenha condições de manter-se atento, evitando os perigos que poderão abalar sua moral e colocar em risco seu governo. Essa característica funciona como uma espécie de sustentação do caráter do indivíduo, dando-lhe a estabilidade e calma necessárias para enfrentar as atribulações. Assim, atuaria de maneira correta abrangendo os princípios éticos e morais vigentes na sociedade a qual pertence (Tini, 2007).

O próximo conselho segue a mesma temática do autoconhecimento, porém nesse Dom Quixote aborda a questão de que Sancho não deve renegar suas origens de ser filho de lavradores. O seu posicionamento frente a tal questão é fundamental para o sucesso de seu governo: “[...] 
ufana-te mais em seres humilde virtuoso que pecador soberbo. [...] se te ufanares de praticar atos virtuosos, não há motivo para ter inveja aos príncipes e senhores, por que o sangue se herda e a virtude adquire-se, e a virtude por si só vale o que não vale o sangue" (Cervantes, 1978, p. 478). Quixote desvincula o exercício do poder da condição do nobre governante, podendo o caráter reto de um humilde lavrador ser mais importante que a linhagem de sangue de um nobre. Isso porque o governo de uma sociedade se constitui de ações e decisões que devem ser acertadas, visto que a vida de inúmeras pessoas estará confiada àquele que exerce o poder. Nesse sentido, as obras apresentadas fazem referência a "príncipes" que possuem a condição de nobre governante, são tratados políticos com recomendações para situações reais e possíveis, diversamente de Sancho que, além de personagem, se tornou um "príncipe" por um acaso do destino.

O quarto conselho remete ao tratamento que Sancho deve ter com seus parentes e esposa. Aqui novamente podemos constatar a anteposição da religião para com a política, como ocorre nos principais manuais de “espelhos de príncipes”: “[...] não o afrontes [os parentes] nem o desdenhes, mas pelo contrário, acolhe-o e agasalha-o, e festeja-o, que satisfarás com isso o céu, que gosta que ninguém se despreze pelo que ele fez" (Cervantes, 1978, p. 478). Outro ponto em destaque nesse conselho é o papel de sua esposa, que deve possuir o mesmo nível de conhecimento do governante, "porque tudo o que ganha um governador discreto, perde-o muitas vezes uma mulher rústica e tola" (Cervantes, 1978, p. 478).

O conselho que Dom Quixote expõe em seguida reflete novamente a doutrina tradicional que é dominante em seu discurso, pois Quixote adverte Sancho, caso ele se torne viúvo e esteja no governo, para não utilizar de seu posto superior para casar-se com alguém por interesse, "porque em verdade te digo que tudo o que a mulher do juiz receber há de dar conta ao marido na residência universal, com que pagará pelo quádruplo na morte o que ilegitimamente recebeu em vida" (Cervantes, 1978, p. 478). Nesse conselho, podemos deslumbrar a prudência - de acordo com a moral da época como uma das características marcantes nos conselhos de Dom Quixote.

A justiça em sua aplicação e prática é o tema dos conselhos seguintes. Após o autoconhecimento, essa é a temática que Dom Quixote mais evidencia, possivelmente por se tratar de uma das tarefas mais importantes 
a serem realizadas por um governador, já que, na época em questão, estava na pessoa do príncipe a responsabilidade de resolver os impasses ocorridos na comunidade - como acontece nos capítulos referentes ao governo de Sancho na Ilha de Barataria.

Dom Quixote chama atenção primeiramente para a interpretação da lei: "Nunca interpretes arbitrariamente a lei, como costumam fazer os ignorantes que têm presunção de agudos" (Cervantes, 1978, p. 478). Ou seja, a interpretação da lei deve ser justa, não havendo inclinações tendenciosas devido à situação de superioridade hierárquica, pois para Quixote quem se prevalece desse pressuposto é ignorante, e um governador não pode possuir tal qualidade negativa. Aqui encontramos o conceito de ratio status que determina como o poder político deve ter em sua essência o agir segundo a justiça, revelando aquilo que o primeiro conselho já determinava a Sancho: o temor a Deus para ter sabedoria, para não ser ignorante. Deste modo, novamente, visualizam-se as diretrizes cristãs entrelaçadas as do político.

Em seguida dois conselhos são apresentados a Sancho referentes à aplicação da justiça, nos quais pobres e ricos se contrapõem. Tais conselhos são interessantes, pois fazem com que alguns estigmas - dos pobres serem sempre favorecidos ou os ricos sempre sofrerem alguma discriminação devido a sua posição - sejam quebrados e um julgamento justo seja feito. Para Quixote deve-se ter compaixão das lágrimas do pobre, porém deve observar as alegações do rico, como também se deve procurar a "verdade por entre as promessas e dádivas do rico, como por entre os soluços e importunidades do pobre” (Cervantes, 1978, p. 478). Novamente observamos a prudência no governar sendo abordada por Quixote em seus conselhos.

O nono conselho, assim como o sexto, reporta-se à questão da equidade. O julgamento deve ser justo, “[...] não carregues com todo rigor a lei no delinqüente, que não é melhor a fama do juiz rigoroso que do juiz compassivo" (Cervantes, 1978, p. 478).

Do sexto ao nono conselhos discriminados e discutidos acima, observa-se que remetem a alguns pontos dos "manuais para príncipes" ou "espelhos dos príncipes":

Sancho responde también a la caracterización del príncipe filósofo pues sabe discernir entre realidad y 
apariencia en los casos que es imprescindible hacerlo para actuar con justicia. [...] en realidad, Sancho no sabe leer ni escribir, con lo que cabría preguntarse de dónde procede el sustrato racional que guía su govierno, la sabiduría que le permite distinguir los principios de lo justo y de lo injusto. Sancho es, en este sentido, indudable portador de una gran dosis de sabiduría popular plasmada en el abundante elenco de refranes de los que hace gala, entendidos éstos como una manifestación de filosofia moal cuya autoridade es señalada [...] (Rivero Iglesias, 2009, p. 122)

Novamente, o próximo conselho possui um cunho religioso, apesar de trazer a justiça como ponto principal: "Se dobrares a vara da justiça, que não seja ao menos com o peso das dádivas, mas sim com o da misericórdia” (Cervantes, 1978, p. 478). Entender o humano e buscar a verdade é a finalidade que Sancho como governador/juiz deve alcançar para assim ser um exemplo e seu governo prosperar.

A imparcialidade do julgador também é abordada por Quixote nos conselhos referentes aos "adornos da alma". No primeiro deles, o cavaleiro aponta para Sancho que, quando vier a deparar-se com um julgamento de uma pessoa pela qual possua algum sentimento pejorativo, deve tentar julgar sem paixão, para não prejudicá-la e também não ferir a si mesmo por fazer um julgamento injusto: "Quando te suceder julgar algum pleito de inimigo teu, esquece-te da injúria e lembra-te da verdade do caso" (Cervantes, 1978, p. 479). Em seguida, referencia um julgamento feito corruptamente para ajudar a outrem, destacando as conseqüências que podem advir: "Não te cegue paixão própria em causa alheia, que os erros que cometeres a maior parte das vezes serão sem remédio, e, se o tiverem, será à custa de teu crédito a até da tua fazenda” (Cervantes, 1978, p. 479). O conselho seguinte segue novamente o mesmo raciocínio, porém destaca o papel da mulher formosa, que pela sua beleza e lágrimas tentará por vezes ludibriar o julgador e tirá-lo a razão.

Por fim, os dois últimos conselhos remetem ao tipo de pena a ser aplicada ao condenado, sugerindo um castigo com obras, porém observando uma condenação justa, "pois bem basta ao desditoso a pena do suplício, sem o acrescentamento das injúrias" (Cervantes, 1978, p. 479). Assinala, também, uma recomendação para que o governante tenha 
piedade e clemência em relação àqueles que estiverem sob sua jurisdição, trazendo novamente à tona os valores católicos em seu aconselhamento:

Ao culpado que cair debaixo da tua jurisdição da nossa depravada natureza, e em tudo quanto estiver da tua parte, sem agravar a justiça, mostra-te piedoso e clemente, por que ainda que são iguais todos os atributos de Deus, mais resplandece e triunfa aos nossos olhos o da misericórdia que o da justiça (Cervantes, 1978, p. 479).

Rivero Iglesias afirma que: "El gobierno de Sancho se guía por los principios del derecho natural, supeditados, eso sí, al derecho canónico y se incorporan, así, como ideal, al derecho positivo" (Rivero Iglesias, 2009, p.123), pois em Dom Quixote é expressado um saudosismo às coisas boas feitas por Sancho, e essas devem hoje estar guardadas em algum lugar.

É evidente a intertextualidade existente entre esse trecho de Dom Quixote e as obras que abordam os "espelhos dos príncipes". Verifica-se que, além de haver a questão religiosa muito saliente na formação do príncipe, também a justiça é um tema recorrente. Esta última vista como uma maneira de garantir ao príncipe o amor e a reputação e ao Estado o estabelecimento da concórdia entre as pessoas. Assim, como Quixote, Botero, por exemplo, traz em primeiro lugar a ideia de justa medida. Evidencia que aquele submetido ao rigor da lei deve ter o direito a uma justa aplicação da sua sentença. Igualmente como no governo de Sancho, nas obras referenciadas, é mostrado o rei como administrador da justiça, porém, elas vão além apontam alguns momentos da História em que os reis com poderes ilimitados começam a comportarem-se como absolutos e a abusar da sua autoridade, privando o acusado de um julgamento justo.

Como destacado anteriormente, excetuando Policraticus, as obras são contemporâneas à de Cervantes e podem ser enquadradas como manuais filosóficos com apontamentos de como governar, diferindo de Dom Quixote que é uma obra romanesca. No entanto, visualiza-se como a prática da justiça apontada por seus escritores exige prudência, um requisito indispensável àqueles que têm a aplicação da justiça sob sua responsabilidade. As obras (com exceção de $O$ príncipe) frisam a justiça aplicada da maneira correta, que garante a tranquilidade do povo e consequentemente a estabilidade do governo. O mau uso ou a má aplicação da justiça é ruim não só para quem dela é objeto, mas para o governante, o qual poderá enfrentar rebeliões em função de seus desmandos e injustiças. 
Dessa forma, observa-se que um governante deve ter suas habilidades governamentais permeadas de discrição e sutilizas, pois a necessidade de afirmar esses dois pontos (virtude e justiça) decorre da imperfeição humana, uma vez que, quando as virtudes se tornam fracas a ponto de alterar a ordem, é necessária a utilização de mecanismos capazes de restaurar a paz e a tranquilidade entre os homens, para garantir a estabilidade do Estado (Tini, 2007).

\section{CONSIDERAÇÕES FINAIS}

Neste trabalho se buscou apresentar os conselhos que Dom Quixote deu a Sancho Pança antes de ele governar a Ilha de Barataria, observando a semelhança entre os "manuais para príncipes" e verificando se Sancho Pança poderia se enquadrar nesse perfil. Como salientado, desde o soneto presente na primeira parte do romance, já existe uma remissão à temática dos "espelhos dos príncipes" com a referência ao cavaleiro de Fedo. Cervantes segue mentalmente, em sua maior parte, dentro da corrente de pensamento medieval e gótico da literatura dos "espelhos dos príncipes".

Quixote abordou diversos dos conselhos necessários para um bom governo, dividiu-os em aqueles que devem "adornar a alma” e aqueles que deveriam "adornar o corpo", preocupou-se em completar Sancho, ou seja, empenou-se em completar o ser humano, composto de corpo e alma. Primeiramente, tratou de cuidar da alma, como visto na discussão feita até o momento, e em seguida elencou os segundos conselhos, para "adornar o corpo”, dispostos no capítulo XLIII, que trazem como principais assuntos as orientações sobre como se vestir, como falar, como se portar a mesa etc. Quixote possuiu a preocupação de fazer com que seu escudeiro atue de acordo com a condição que está prestes a encarar: ter o bom senso e a cautela para com seus modos, para então ter a confiabilidade dos seus governados em suas ações. Diante disso, concluí-se que os conselhos possuem como função fazer de Sancho um bom governador, para que na sua forma de governar sobressaia a arte da prudência, ao invés da “engenharia política” maquiavélica.

A exposição das primeiras linhas do romance para então chegar ao episódio selecionado para a discussão ressaltou como as características próprias de cada um dos dois personagens (Dom Quixote e Sancho Pança) 
são fundamentais para o desfecho dessa passagem que traz em sua narrativa o direito explícito, pois o governante era aquele que julgava. Assim, Sancho seria o juiz e Dom Quixote, por saber das dificuldades do amigo, resolveu ajudá-lo, já que sabia do fato de que vidas seriam decididas por ele e suas decisões interfeririam no cotidiano da sociedade que estaria subordinada a ele.

Dessa forma, constatando o quanto o direito está presente na obra de Cervantes, o aspecto abordado é apenas um em meio a outros que podem ser debatidos, inúmeros são os ângulos que os juristas podem observar para humanizar suas ações. Cintrón aponta que:

\begin{abstract}
[...] la obra de Cervantes, uma búsqueda continua de la liberdad, la justicia, y el Derecho ante las fuerzas deletéreas que los combraten. De ahí sus hermosas palabras sobre la liberdad, el 'humano tesoro'. [...] Los temas jurídicos expuestos, los contrastes, las antinomias, las contracicciones y todo el fermento quijotesco relacionado con el Derecho, la Justicia, la equidad y los problemas perennes de la administración de la justicia que introducen al abogado y a los legos em contenidos de profunda importancia y actualidad (Cintrón, 2010, p. 135).
\end{abstract}

O aspecto social e a representação da realidade da época - e que por vezes parecem tão atuais - nos permite uma análise do direito para além do positivismo predominante na formulação jurídica contemporânea. Os personagens Dom Quixote e Sancho Pança são representações de sujeitos de direito: no caso de Sancho, o juiz; e Quixote, o instrutor, que ajudou na concretização de seu governo e o tornou, mesmo que por alguns dias, um "príncipe" digno de seu reinado.

\title{
REFERÊNCIAS
}

ARISTÓTELES. Arte retórica e arte poética. 16. ed. Rio de Janeiro: Ediouro, [19--]. 290p.

BERCOVICI, Gilberto. O estado de exceção e a garantia do Estado. In: BERCOVICI, Gilberto. Soberania e Constituição: para uma crítica do constitucionalismo. São Paulo: Quartier Latin, 2008. 384p.

CALVO GONZÁLEZ, José. Derecho y literatura. Intersecciones instrumental, estructural e institucional. In: CALVO GONZÁLEZ, José. Implicación derecho literatura: contribuciones a una teoría literaria del derecho. Granada: Comares, 2008. p. 3-27.

CERVANTES DE SAAVEDRA, Miguel de. Dom Quixote de La Mancha. São Paulo: Abril Cultural, 1978. 609p. 
CINTRÓN, Carmelo Delgado. El mundo jurídico de Don Quijote. Revista de La Academia Puertorriqueña de Jurisprudencia y Legislación. San Juan, n. VIII, p. 132-243, 2010.

DWORKIN, Ronald. Uma questão de princípio. São Paulo: Martins Fontes, 2000. 593p.

FACHIN, Melina Girardi. Utopia quixotesca dos direitos humanos. Anamorphosis - Revista Internacional de Direito e Literatura, v. 3, n. 1, p. 153-169, janeiro-junho $2017 . \quad$ Doi: http://dx.doi.org/10.21119/anamps.31.153-169.

FERRAZ JUNIOR, Tercio Sampaio. Função social da dogmática jurídica. São Paulo: Max Limond, 1998. 205p.

GODOY, Arnaldo Sampaio de Moraes. Direito e literatura: anatomia de um desencanto. Curitiba: Juruá, 2002. 18op.

KRISTEVA, Julia. Introdução à semanálise. São Paulo: Perspectiva, 1974. $391 \mathrm{p}$.

JUNQUEIRA, Eliane Botelho. Literatura e direito: uma outra leitura do mundo das leis. Rio de Janeiro: Letra Capital, 1998. 238p.

MESQUITA, António Pedro. Natureza e finalidade da retórica. In: ARISTÓTELES. Retórica. 2.ed. Lisboa: Imprensa Nacional; Casa da Moeda, 2005.

Disponível

em:

$<$ https://sumateologica.files.wordpress.com/2009/o7/aristoteles -

retorica2.pdf >. Acesso em: 12 dez. 2015.

OLIVO, Luiz Carlos Cancellier de. O estudo do Direito através da literatura. Tubarão: Studium, 2005. 104p.

OLIVO, Luis Carlos Cancellier de; LEHMANN, Leonardo Henrique Marques. Dimensão jurídica da loucura e modelos de atenção à saúde mental em Dom Quixote. Anamorphosis - Revista Internacional de Direito e Literatura, v. 1, n. 1, p. 99-120, janeiro-junho 2015. Doi: http://dx.doi.org/10.21119/anamps.11.99-120.

RIVERO IGLESIAS, María del Carmen. El bien común en el Quijote el gobieno de Sancho en la Ínsula Barataria. In: ARELLANO, Ignacio; STROSETZKI, Christoph; WILLIAMSON, Edwin (Org.). Autoridad y poder en el siglo de oro. Madrid: Iberoamericana, 2009. p. 117-136.

RINCÓN, David Nogales. Los Espejos de Príncipes en Castilla (Siglos XIIIXV): un modelo Literario de la Raleza Bajomedieval. Revista de la Sociedad Española de Estudios Medievales, n. 16, p. 9-39, 2006.

SUÁREZ QUEVEDO, Diego. De "Espejos de Príncipes" y afines, 1516-1658: arte, literatura y monarquía en el ámbito hispano. Anales de historia del arte, n. 19, p. 117-156, 2009.

TINI, Valéria. A (in)discrição: aspectos do decoro em Dom Quixote de Miguel de Cervantes. 2007. 125 f. Dissertação (Mestrado em Literatura Moderna) - Faculdade de Filosofia, Letras e Ciências Humanas, Universidade de São Paulo, São Paulo, 2007.

VIEIRA, Maria Augusta da Costa. O dito pelo não-dito: paradoxos de Dom Quixote. São Paulo: EDUSP; FAPESP, 1998. 184p. 
WATT, Ian. Mitos do individualismo moderno: Fausto, Dom Quixote, Dom Juan, Robinson Crusoe. Rio de Janeiro: Zahar, 1997. 316p.

Idioma original: Português

Recebido: 19/12/17

Aceito: 08/08/18 